\title{
PEMBERDAYAAN MASYARAKAT DESA OLELE MELALUI PELATIHAN PEMBUATAN NUGET IKAN NIKE KELOR DAN CAKE KELOR
}

\author{
Masra Latjompoh ${ }^{1^{*}}$, Margaretha Solang ${ }^{2}$ \\ ${ }^{1,2}$ Universitas Negeri Gorontalo \\ *Corresponding Author Email: martasolang@yahoo.co.id
}

(Artikel Masuk: 12 Oktober 2020; Artikel Diterima: 19 Desember 2020; Artikel Terbit: 26 Desember 2020)

\begin{abstract}
Olele village in Kabila Bone district is among the villages located in the southern coastal area of the province of Gorontalo. The majority of people there work as fishermen and farmers. Nike fish (Awaous melanocephalus) and moringa (Moringa oleifera) are the common natural resources in Olele village. The objective of this mentoring project was to enhance the food processing skills of the local community by disseminating steps in processing moringa nike fish nugget and the potential of the leaves of a moringa as the ingredient of moringa leaf cake. Its steps included 1) preparation, 2) program implementation, and 3) evaluation. Based on the results, the mentoring program contributed to the enhancement of both knowledge and skills of the participants in processing nugget of moringa nike fish. The participants were also aware of the potential of the leaf moringa as an ingredient of a healthy diet. Further, all participants were able to make moringa nike fish nugget and moringa leaf cake. These two food products received a positive reception from all panelists. In the end, all participants would improve all of the food products through their home-based food business. This was also to support the food business program in their village.
\end{abstract}

Keywords: Moringa oleifera, Awaous melanocephalus, food, Olele village

\begin{abstract}
Abstrak
Desa Olele Kecamatan Kabila Bone merupakan salah satu desa yang terletak di pesisir selatan Provinsi Gorontalo. Masyarakat desa Olele sebagian besar bekerja sebagai nelayan dan petani. Ikan nike (Awaous melanocephalus) dan kelor (Moringa oleifera) merupakan sumber daya alam yang ditemukan di Desa Olele. Tujuan kegiatan ini adalah meningkatkan pengetahuan dan ketrampilan peserta dalam pengolahan nuget ikan nike kelor, meningkatkan pengetahuan peserta tentang potensi daun kelor sebagai bahan makanan sehat, meningkatkan ketrampilan peserta dalam pengolahan kelor, dan menghasilkan produk nuget ikan nike kelor dan cake kelor. Metode kegiatan yang digunakan adalah pendampingan dengan tahapan kegiatan; 1. persiapan, 2.pelaksanaan, 3. evaluasi. Hasil kegiatan menunjukkan adanya peningkatan pengetahuan dan ketrampilan peserta dalam mengolah nuget ikan nike kelor, peserta telah mengetahui bahwa daun kelor memiliki potensi gizi yang baik dan dapat dikembangkan sebagai bahan olahan makanan sehat, dan peserta telah terampil dalam mengolah ikan nike dan kelor menjadi nuget ikan nike kelor dan cake kelor. Produk olahan ikan nike kelor dan cake kelor dapat diterima oleh panelis pada taraf disukai. Hasil kegiatan ini akan dikembangkan oleh peserta dalam usaha kue mereka dalam skala rumah tangga untuk mendukung program warung kuliner
\end{abstract}

Kata Kunci: kelor, ikan nike, pangan, desa Olele 


\section{A. PENDAHULUAN}

Desa Olele Kecamatan Kabila Bone merupakan salah satu desa yang terletak di pesisir selatan Provinsi Gorontalo yang menghadap ke Teluk Tomini. Masyarakat desa Olele sebagai besar bekerja di bidang perikanan, khususnya sebagai nelayan (Salam et al., 2016). Sementara yang lain bekerja sebagai petani. Sebagai nelayan, masyarakat mengandalkan pendapatannya dari potensi hasil laut, hal ini berdampak pada kesejahterahan keluarga. Berdasarkan data desa tahun 2020 terlihat bahwa data jumlah keluarga prasejahterah 32\%, keluarga prasejahterah 1 sebesar 64,69\%, keluarga prasejahterah 2 sebesar 3,3\%. Besarnya persentase keluarga prasejahterah menunujukkan bahwa pendapatan masyarakat masih belum optimal. Oleh karena itu perlu memaksimalkan pendapatan keluarga dengan meningkatkan pengolahan potensi sumber daya alam baik laut maupun darat.

Potensi sumber daya laut desa Olele antara lain ikan tuna, cumi -cumi, dan ikan nike. Ikan nike (Awaous melanocephalus) merupakan jenis ikan yang digemari masyarakat Gorontalo. Ikan nike merupakan family Gobiidae, merupakan native species (spesies asli) di beberapa daerah di Sulawesi. Awaous melanocephalus di Mamuju disebut ikan penja (Muthiadin et al., 2017). Pengolahan ikan nike yang sudah dilakukan oleh masyarakat diantaranya perkedel nike dan ikan nike garo.

Selain memiliki potensi perikanan, desa Olele juga memiliki potensi tanaman kelor. Tanaman kelor (Moringa oleifera Lam) mengandung vitamin $\mathrm{E}$ atau tokoferol yang berfungsi sebagai antioksidan. Kandungan vitamin $\mathrm{E}$ ini terdapat baik pada daun yang muda maupun daun yang tua (Mubarak et al., 2017). Sementara itu daun kelor asal Gorontalo mengandung protein yang cukup tinggi 28,5\% (Solang et al., 2019). Kelor hanya dimanfaatkan oleh masyarakat sebagai pakan ternak dan belum dimanfaatkan sebagai bahan pangan. Hal ini menunjukkan bahwa tanaman kelor belum dimanfaatkan secara optimal sebagai bahan pangan yang memiliki potensi untuk mendukung pemenuhi gizi keluarga dan perbaiki ekonomi keluarga. Oleh karena itu telah dilakukan pengenalan kandungan gizi dan teknik pengolahan kelor sebagai makanan sehat melalui kegiatan pendampingan.

Potensi ikan nike dan kelor yang terdapat di desa Olele perlu dikembangkan untuk mendukung pemenuhi gizi keluarga dan perbaikan ekonomi keluarga. Olahan ikan nike dapat divariasikan dengan menambahkan daun kelor dalam produk olahan. Nuget nike kelor merupakan salah satu produk yang dapat disimpan lebih lama. Namun olahan nuget nike kelor ini belum banyak diketahui oleh masyarakat sehingga telah dilakukan 
pengenalan teknik pengolahan ikan nike dan kelor menjadi produk nuget melalui kegitan pendampingan. Mengingat ikan nike banyak digemari oleh masyarakat maka variasi pengolahan ikan ini memiliki potensi besar disukai oleh masyarakat.

Pengolahan nike dan kelor menjadi nuget dan pengolahan kelor menjadi cake kelor merupakan variasi olahan yang memiliki potensi ekonomi. Variasi olahan ikan nike dan kelor ini memiliki potensi ekonomi karena olahan nike dapat menjadi buah tangan bagi pengunjung pantai Olele. Pantai olele merupakan tempat wisata yang indah dengan pengunjung yang cukup banyak. Pengolahan produk nuget ikan nike kelor dan produk cake kelor ini secara teknis muda dilakukan oleh masyarakat karena bahan, alat dan cara pembuatan produk hanya menggunakan teknik sederhana. Produk hasil olahan ini akan dikemas sederhana namun menarik sehingga menarik pembeli untuk menjadikan buah tangan asal desa Olele merupakan desa wisata laut yang indah.

Kegiatan pendampingan pengolahan produk nuget ikan nike kelor dan cake kelor ini diharapkan dapat mendukung program pemerintah dalam memperbaiki kesejahterahan masyarakat dan mendapatkan olahan pangan sehat. Program kegiatan ini melibatkan dosen dan mahasiswa Universitas Negeri Gorontalo. Dosen yang terlibat dalam kegiatan ini telah memiliki pengalaman dalam pengolahan produk perikanan dan produk olahan daun kelor. Khalayak sasaran dalam kegiatan ini adalah ibu-ibu/ istri nelayan dan karang taruna desa Olele. Kegiatan pengabdian ini melibatkan kerjasama dengan pemerintah desa, dan tokoh masyarakat, Pelaksanaan program kegiatan ini bertujuan untuk meningkatkan pengetahuan dan ketrampilan peserta dalam pengolahan nuget ikan nike kelor, meningkatkan pengetahuan peserta tentang potensi daun kelor sebagai bahan makanan sehat, meningkatkan ketrampilan peserta dalam pengolahan cake kelor, dan menghasilkan produk nuget nike kelor dan cake kelor. Kegiatan pengabdian ini menghasilkan produk makanan yang berupa nuget ikan nike yang disuplementasi tepung daun kelor dan cake dengan suplementasi tepung daun kelor. Setelah pelaksanaan kegiatan ini diharapkan masyarakat termotivasi untuk mengembangkan olahan nike dan daun kelor menjadi produk yang inspiratif sebagai usaha dalam skala rumah tangga untuk meningkatkan pendapatan keluarga dan mendukung program desa Olele, yaitu warung kuliner.

\section{B. PELAKSANAAN DAN METODE}

Kegiatan pengabdian ini dilaksanakan di desa Olele, Kecamatan Kabila Bone, Kabupaten Bone Bolango Provinsi Gorontalo. Pelaksanaan kegiatan pengabdian dilakukan dalam 3 tahap. Tahap pertama merupakan 
tahap kegiatan yang diawali dengan observasi lokasi kegiatan dan diskusi antara tim pengabdi kepada masyarakat (PKM) dengan pemerintah desa dan masyarakat tentang waktu pelaksanaan kegiatan, serta diskusi antara tim pengabdi tentang materi kegiatan.

Tahap kedua merupakan tahap pelaksanaan kegiatan. Metode pelaksanaan kegiatan untuk mengatasi masalah mitra adalah pendampingan; kepada masyarakat melalui kelompok ibu rumah tangga (istri nelayan) dan karang taruna. Materi pendampingan terdiri dari: pendampingan dan pelatihan pembuatan nuget ikan nike dan cake yang disuplementasi tepung daun kelor. Selanjutnya dilakukan uji organoleptik terhadap produk yang dihasilkan untuk mengetahui tingkat penerimaan masyarakat terhadap produk yang dihasilkan. Kegiatan ini diikuti oleh 15 peserta yang terdiri dari ibu rumah tangga yang tergabung dalam kelompok isteri nelayan dan karang taruna.

Tahap ketiga merupakan tahap akhir kegiatan, dalam tahap ini di lakukan evaluasi. Evaluasi dilakukan untuk mengetahui wawasan dan pengetahuan peserta tentang olahan ikan nike, kandungan gizi kelor, olahan daun kelor. Evaluasi ini dilakukan dengan dengan wawancara dan kuosioner.

\section{HASIL DAN PEMBAHASAN}

Hasil dari kegiatan pendampingan ini menunjukkan bahwa masyarakat peserta kegiatan telah memahami kandungan gizi dan manfaat daun kelor sebagai bahan pangan. Masyarakat juga telah mampu membuat nuget nike yang disuplemnetasi tepung kelor dan cake yang disuplementasi tepung daun kelor. Saat penyampaian materi tentang ikan nike, tanaman kelor, dan kandungan gizinya mendapat respon yang sangat baik.

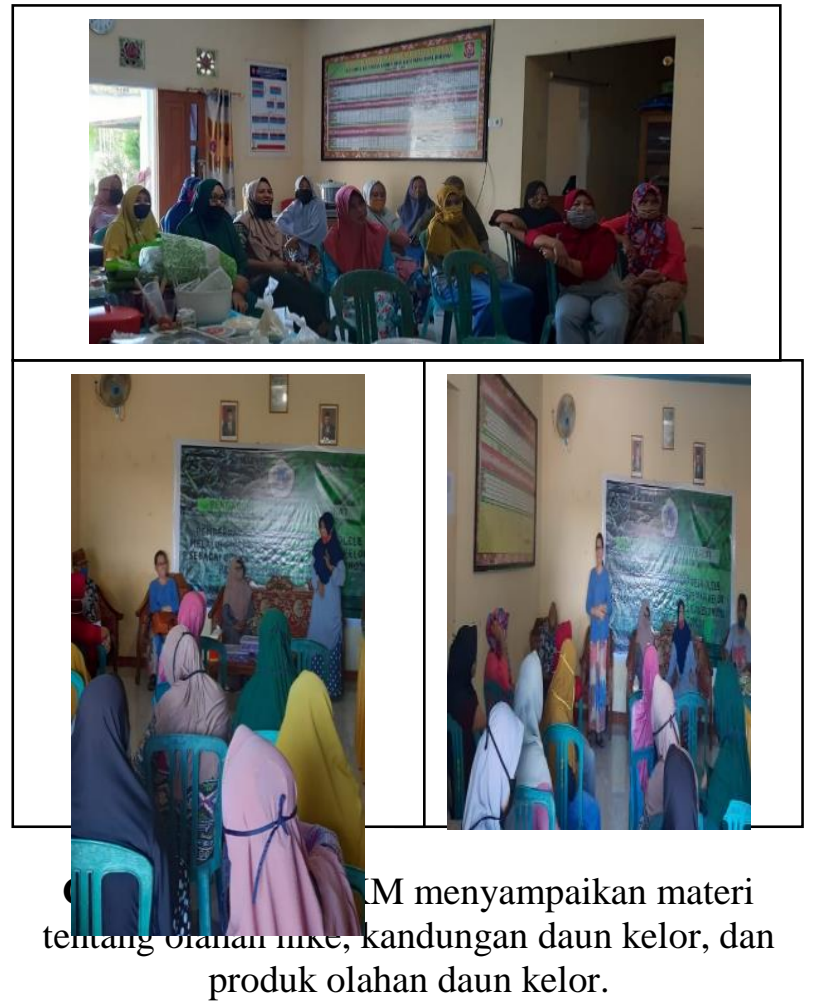

Masyarakat antusias dalam merespon pertanyaan pemateri dan masyarakat juga memberikan pertanyaan terkait materi. Pertanyaan yang diberikan oleh pemateri dimaksudkan sebagai langkah untuk mengevaluasi pemahaman peserta pendampingan, disajikan dokumentasi saat penyampaian materi kegiatan (Gambar 1).

Kegiatan berikut adalah praktek pembuatan nuget ikan nike cake yang 
disuplementasi tepung daun kelor. Kelompok peserta dibagi menjadi 2 kelompok. Sebelum pelaksanaan kegiatam tim PKM menjelaskan bahan-bahan yang digunakan dalam pembuatan nuget ikan kelor dan cake kelor yang disuplementasi kelor. Bahan -bahan yang digunakan dalam kegiatan pendampingan dan pelatihan pembuatan nuget dan cake kelor sebagai berikut.

1. Nuget ikan nike (Gambar 2) yang disuplementasi tepung kelor (Gambar 3).

Bahan yang digunakan adalah ikan nike $1 \mathrm{~kg}$, tepung daun kelor $30 \mathrm{~g}$, tepung maizena $300 \mathrm{~g}$, tepung terigu 100 gram, bawang merah $100 \mathrm{~g}$, bawang putih $50 \mathrm{~g}$, lada $13 \mathrm{~g}$, garam 8 $\mathrm{g}$, telur ayam 2 butir. Semua bumbu yang digunakan dihaluskan terlebih dahulu. Nuget ikan nike yang di suplementasi tepung kelor dibuat dengan cara sebagai berikut, ikan nike dicuci dan dibersihkan dari kotoran-kotoran yang terikut saat pengambilan, ikan nike dihaluskan menggunakan blender. Ikan nike yang sudah dihaluskan dicampur dengan bumbu-bumbu yang sudah dihaluskan diaduk hingga homogen. Selanjutnya ditambahkan telur, tepung maizena, tepung kelor, dan tepung terigu, diaduk hingga menjadi adonan yang homogen.

Adonan nugget diletakkan dalam wadah dan dikukus selama 20-30 menit. Setelah proses pengukusan nugget didinginkan untuk memudahkan ketika dipotong-potong menjadi ukuran yang lebih kecil sesuai selera.
Selanjutnya nuget ikan nike kelor dicelupkan dikocokan telur, dilumuri dengan tepung roti (breading). Nuget mentah dapat disimpan dalam freezer sekitar 30 menit agar tepung panir menempel dengan baik atau dapat juga langsung di masak/ digoreng untuk dikonsumsi.

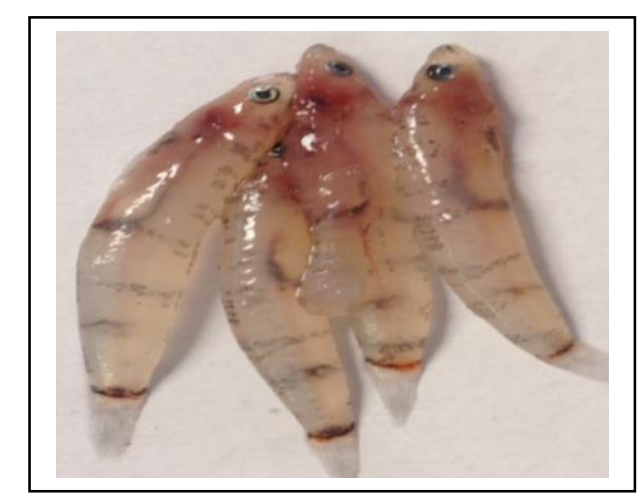

Gambar 2. Ikan nike

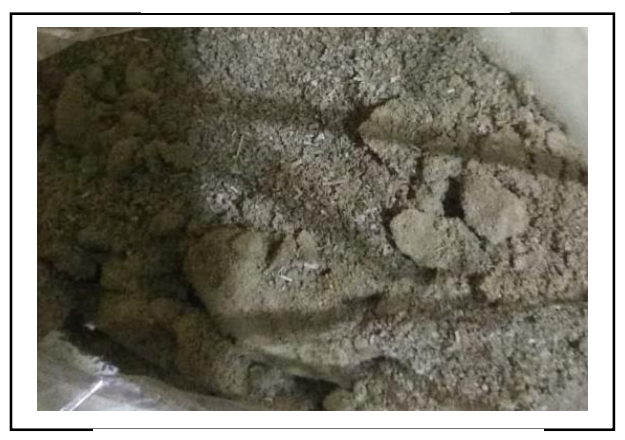

Gambar 3. Tepung kelor

2. Cake yang disuplementasi tepung daun kelor

Bahan yang digunakan dalam pembuatan cake yang disuplementasi kelor adalah telur 5 butir, terigu $250 \quad \mathrm{~g}, \quad$ gula pasir $100 \mathrm{~g}$, mentega $50 \mathrm{~g}$ (dilelehkan), tepung kelor $3 \mathrm{~g}$, dan emulsifier $1 / 2$ sendok teh. Cara membuat cake yang disuplementasi tepung kelor sebagai berikut: telur, gula pasir dan emulsifier dimixer speed 3 sampai adonan 
mengental dan mengembang, Selanjutnya memasukkan tepung terigu yang telah dicampur dengan bubuk kelor ke dalam adonan, aduk perlahan. Berikutnya memasukkan mentega cair ke dalam adonan, aduk sampai tercampur rata. Adonan yang sudah homogen dituangkan ke dalam cetakan yang telah diolesi mentega. Adonan selanjutnya dipanggang dengan api sedang hingga matang, setelah matang didinginkan dan disiap di sajikan. Berikut disajikan dokumentasi praktek pembuatan nuget ikan nike dan cake yg disuplementasi tepung daun kelor.

Setelah selesai kegiatan praktek pembuatan nuget ikan nike kelor dan cake kelor dilakukan uji organoleptik terhadap produk-produk tersebut. Uji organoleptik dilakukan pada 15 orang peserta. Tingkat penerimaan panelis ini dikategorikan dalam 6 kategori tingkat kesukaan dengan urutan sebagai berikut: $6=$ Amat sangat suka; $5=$ Sangat suka ; 4= Suka; 3= Agak suka; 2= Agak tidak suka; dan 1= Sangat tidak suka.

Hasil uji organoleptik nuget ikan nike yang di suplementasi tepung kelor menunjukkan bahwa panelis dapat menerima produk nuget ikan nike kelor baik dari segi rasa warna, aroma dan tekstur (Gambar 5).
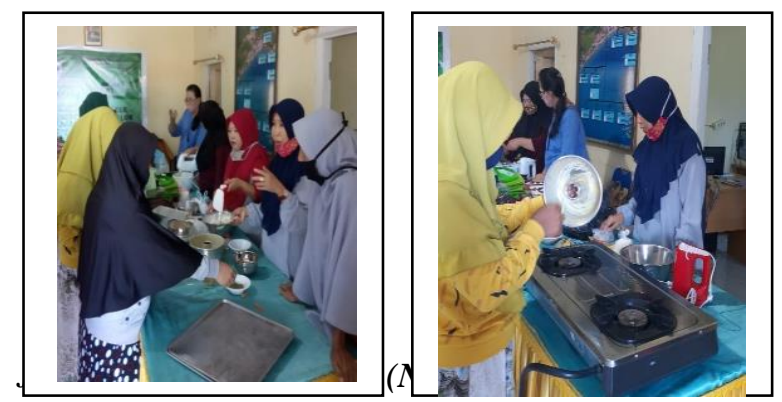

Gambar 4. Tim PKM bersama masyarakat mempraktekkan pembuatan nuget ikan nike dan cake yang disuplemnetasi tepung kelor.

Rasa nuget ikan nike kelor diterima oleh panelis pada dengan nilai 4,8 ini berarti panelis dapat menerima rasa nuget mendekati kriteria sangat suka. Tekstur nuget ikan nike kelor diterima panelis pada taraf mendekati sangat suka (4,5). Warna nuget ikan nike kelor dapat diterima oleh panelis pada kriteria mendekati sangat suka (4,5). Panelis memberikan penilaian terhadap aroma nuget ikan nike kelor sebesar 4,6, artinya bahwa aroma nuget ini dapat diterima oleh panelis pada kriteria mendekati sangat suka.

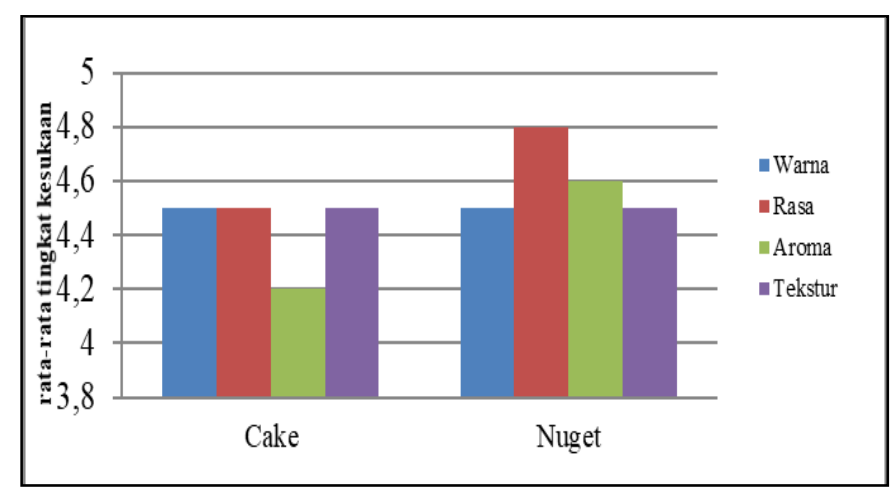

Gambar 5. Tingkat kesukaan panelis terhadap nuget ikan nike dan cake yang disuplementasi tepung kelor.

Respon organoleptik cake kelor yang diberikan oleh panelis juga menunjukkan bahwa cake kelor dapat diterima oleh panelis baik dari segi rasa, aroma, tekstur, dan warna. Rasa cake kelor diterima oleh panelis pada taraf kesukaan sebesar 4,5, hal ini berarti panelis dapat menerima rasa cake kelor pada 
kriteria yang mendekati sangat suka. Tekstur cake kelor dapat diterima panelis pada taraf kesukaan 4,5, yang berarti tekstur cake kelor disukai oleh panelis. Panelis memberikan penilaian terhadap warna cake kelor sebesar 4,5, ini menunjukkan bahwa warna cake kelor di sukai oleh panelis. Aroma cake kelor juga diterima oleh panelis pada kriteria suka dengan nilai 4,2 .

Berdasarkan hasil uji organoleptik nuget ikan nike kelor dan cake kelor ini menunjukkan bahwa penambahan tepung kelor pada produk makanan tidak mengubah kesukaan panelis terhadap produk. Hasil uji ini menunjukkan bahwa suplementasi kelor pada kriteria aroma cake kelor memiliki ratarata kesukaan yang paling rendah dibanding rata-rata kesukaan dari kriteria lainnya.

Masyarakat desa Olele memberikan respon yang besar terhadap produk nuget ikan nike kelor dan cake kelor. Setelah mengikuti kegiatan pendampingan ini masyarakat ingin melanjutkan pengolahan kelor ini secara mandiri. Kegiatan Masyarakat ini diharapkan dapat membuka wawasan masyarakat tentang potensi alam baik laut maupun darat yang dapat dimanfaatkan untuk pemenuhan gizi dan kesejaterahan keluarga. Selain itu kegiatan ini dapat menununjang program warung kuliner desa Olele.

Tahap akhir kegiatan dilakukan evaluasi dengan melakukan kegiatan diskusi antara tim PKM dan ibu-ibu peserta pendampingan terkait pengetahuan yang telah diperoleh tentang kandungan gizi ikan nike dan kelor serta teknik pengolahannya menjadi nuget ikan nike kelor dan cake kelor.

Berdasarkan hasil diskusi dan jawaban pada koesioner menunjukkan bahwa 90\% peserta kegiatan PKM ini telah memahami bahwa daun kelor yang selama ini hanya dimanfaatkan sebagai pakan ternak ternyata memiliki potensi gizi yang baik dan dapat dikembangkan sebagai bahan olahan makanan. Peserta juga telah memahami bahwa ikan nike dapat diolah menjadi nuget dengan menambahkan tepung kelor. Hasil evaluasi juga menunjukkan bahwa peserta telah memiliki ketrampilan dalam mengolah ikan nike dan kelor menjadi nuget dan peserta juga telah memiliki ketrampilan dalam membuat cake kelor dan menunjukkan bahwa peserta ingin mengembangkan olahan pangan ini dalam usaha kue mereka dalam skala rumah tangga.

\section{PENUTUP}

\section{Simpulan}

Berdasarkan hasil kegiatan pengabdian ini maka dapat disimpulkan bahwa masyarakat khususnya ibu-ibu nelayan desa Olele telah memahami diversifikasi olahan ikan nike. Masyarakat telah memahami bahwa kelor adalah bahan pangan yang bergizi dan dapat dimanfaatkan dalam berbagai olahan. Selain itu, masyarakat telah memiliki ketrampilan 
dalam pengolahan nuget ikan nike dan cake yang disuplementasi kelor. Produk nuget ikan nike kelor dan cake kelor disukai oleh masyarakat baik dari segi warna, rasa, aroma, dan tekstur. Kegiatan ini memberikan pengetahuan baru bagi masyarakat sehingga mereka dapat secara maksimal memanfaatkan sumber daya alam kelor yang tersedia di desa mereka.

\section{Saran}

Kegiatan ini telah menginspirasi masyarakat untuk memvariasikan olahan ikan nike dan membuka wawasan masyarakat dalam memanfaatkan kelor sebagai bahan pangan, oleh karena itu perlu dilakukan kegiatan selanjutnya yang berupa pemasaran online sehingga produk masyarakat dapat dikenal lebih luas.

\section{Ucapan Terima Kasih}

Kegiatan pengabdian ini dapat terlaksana karena dukungan beberapa pihak, oleh karena itu kami menyampaikan terima kasih kepada Program Pasca Sarjana Universitas Negeri Gorontalo yang telah mendanai kegiatan ini melalui dana PNBP Pasca Sarjana 2020. Ketua LP2M Universitas Negeri Gorontalo yang telah menyetujui pelaksanaan kegiatan ini dan Kepala Desa dan masyarakat Desa Olele, Kecamatan Kabila Bone Kabupaten Bone Bolango yang telah bersedia bermitra dalam kegiatan ini.

\section{E. DAFTAR PUSTAKA}

Mubarak, K., Natsir, H., Wahab, A. W., \& Satrimafitrah, P. (2017). Analysis of $\alpha$ tokopherol (Vitamin E) extracted from moringa leaves (Moringa oleifera Lam) collected from seashore and highland areas and its Potencyal as Antioxidant. Kovalen, $3(1), 78-88$.

Muthiadin, C., Aziz, I. R., \& Andriyani, A. A. (2017). Awaous melanocephalus: Ikan Native Species Dari Sulawesi Barat (Sebuah Review). Prosiding Seminar Nasional Biology for Life, 3(November), 55-59.

Salam, A., Hamzah, S. N., Perairan, M. S., \& Perikanan, F. (2016). Kearifan Lokal Masyarakat Nelayan Desa Olele. Nike: Jurnal Ilmiah Perikanan dan Kelautan.4 (2).85-90.

Solang, M., Baderan, D. W. K., \& Kumaji, S. S. (2019). Balita Stunting Melalui Pemanfatan Pangan Lokal Di Kabupaten Pohuwato Provinsi Gorontalo. 25(2), 85-90. 